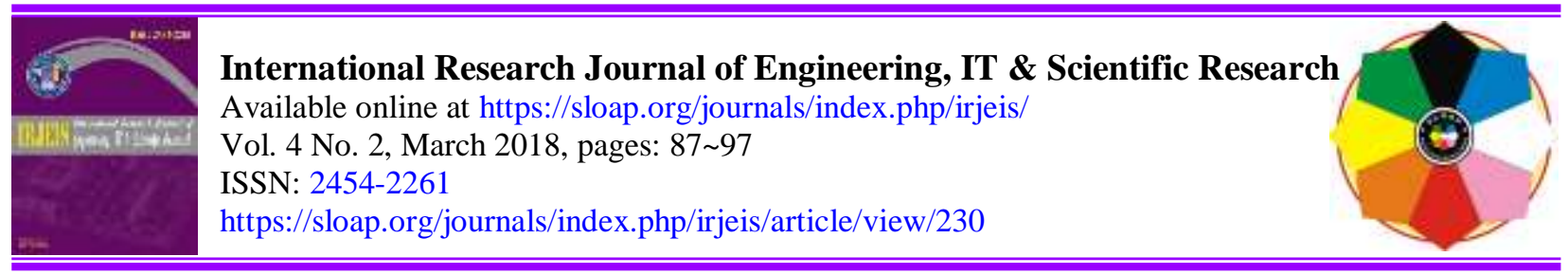

\title{
Task-Based Learning and Student Team Achievement Division on Students Motivation and Reading Achievement (An Experimental Studies)
}

\author{
Lisa Dewi Purnama Sari ${ }^{a}$ \\ Arifuddin ${ }^{b}$ \\ Kamaludin Yusra $^{c}$
}

Article history:

Received: 10 November 2017

Revised: 25 February 2018

Approved: 20 March 2018

Published: 30 March 2018

\section{Keywords:}

Motivation;

Reading Achievement;

Task-Based Learning;

Student Team Achievement

Division;

\begin{abstract}
This study aimed at identifying the effect of Task-Based Learning (TBL) on students' motivation and reading achievement, the effect of Student Team Achievement Division (STAD) on students' motivation and reading achievement, and the difference in the effect of Task-Based Learning (TBL) and Student Team Achievement Division (STAD) on students' motivation and reading achievement. The sample of this research was the grade $\mathrm{X}$ students of SMAN 2 Aikmel in academic year 2017/2018. This research used true experimental with pre-test and post-test only designs. Quantitative analysis was done by using two-way ANOVA for hypotheses testing. After analyzing the data, the result of the research showed that TBL was effective to improve the students' reading achievement and was also effective to increase the students' motivation. In the same way, when the test was applied to STAD class, the result indicated that STAD also had efficacy to enhance students' reading achievement and to increase students' motivation. Furthermore, from the result of the research, it was clear that TBL and STAD had no different results in improving students' reading achievement and motivation. Thus, from the result of the analysis it could be concluded that there was significant effect of Task-Based Learning (TBL) on students' motivation and reading achievement; there was significant effect of Student Team Achievement Division (STAD) on students' motivation and reading achievement; and there was no any significant difference in the effect of Task-Based Learning (TBL) and Student Team Achievement Division (STAD) on students' motivation and reading achievement.
\end{abstract}

2454-2261 ${ }^{\circ}$ Copyright 2018. The Author. This is an open-access article under the CC BY-SA license (https://creativecommons.org/licenses/by-sa/4.0/) All rights reserved.

\footnotetext{
a Mataram University, Indonesia

${ }^{\mathrm{b}}$ Mataram University, Indonesia

${ }^{\mathrm{c}}$ Mataram University, Indonesia
} 


\section{Author correspondence:}

Lisa Dewi Purnama Sari,

English education course at the Mataram University, Indonesia

Email address: nonalisa77@gmail.com

\section{Introduction}

To master the English language, the teachers at school should find the best and the most appropriate method for their students and teachers should be able to conduct a good teaching and learning process. However, in fact, most of the teachers do not give what the learners should gain. In teaching, for example, most of the teachers are still used conventional methods. These methods are truly teacher-centered instruction that emphasizes the grammatical and vocabulary. Therefore, the students cannot develop their true ability and surely they fail to develop their proficiency.

One skill of language which plays an important role in learning is reading. Reading is one of the most complex forms of information processing and is probably the most extensively researched language skill. Recent research on reading has shown that reading is a complex cognitive activity that is indispensable for adequate functioning and for obtaining information in contemporary society. Without having adequate reading skills, students will have difficulty in learning. Reading skill is abasic competence, not the only for learning the language itself, but also for learning other subjects. By reading, students will be able to acquire knowledge, which is very useful for the growth and development of logical reasoning, social, and emotional. Considering the important role of reading for the development of students, then teachers should use appropriate media and methods in teaching reading comprehension.

English reading skill has been taught for a long time and teachers in the school have used many methods in teaching reading skills. However, the result of teaching English reading skill is still considered unsatisfactory and many of these methods were less effective to be used in teaching reading and even considered irrelevant. This condition makes the students feel anxiety and hard to achieve the learning objectives. Therefore, these students need strategies in order to overcome the problems. Considering the importance of reading comprehension, this study is intended to describe the teaching of reading comprehension strategies to students.

To overcome this learning problem, the researcher will try to apply Task-Based Learning (TBL) method. With this method, the students may learn more effectively when their minds are focused on the task, rather than on the language they are using. Task-Based Learning can also be regarded as one particular approach to implement the broader communicative approach in general. The aim of Task-Based Learning is to develop students' ability to communicate and communication takes place by using the grammatical system of the language. In addition, what makes Task-Based Learning interesting is that its characteristics itself in which students in a pair or a small group is engaged in doing the task. However, it is not as straightforward as just doing one task after another. It can be said that Task-Based Learning provided an alternative approach to focusing on language. It has the key benefit of allowing students in some degree of choice in terms of what language they learn while working on tasks. Another characteristic that should be highlighted is that Task-Based Learning primes itself on the learner-centered approach. In this understanding, it draws knowledge from learners, working through their needs and interests and selecting materials, activities, and tasks accordingly.

The other method can encourage students' participation in the learning process is Student Team Achievement Division (STAD). STAD is part of cooperative learning with the concept of a small group working together to accomplish a shared learning goal. It is a teaching strategy which allows students to work together in small groups with individuals of various talents, abilities, and background to accomplish a common goal. STAD is recognized as the one approach that is effective to increase students' achievement in learning. Therefore, it can be said that STAD can be an alternative method that gives satisfaction for both teacher and students in teaching and learning process.

The success of learning is also determined by motivation. Motivation is the robust power that leads the students to gain better result in learning. But motivation is not stand alone. To be motivated, the students, of course, need a comfort and pleasant environment.

Based on the conditions above, the researcher intends to conduct a research by seeing the different influence of motivation and reading achievement through the application of Task-Based Learning and Student Team Achievement Division method.

The main purposes of this research are: (1) To identify the effect of Task-Based Learning (TBL) on students' motivation and reading achievement; (2) To identify the effect of Student Team Achievement Division (STAD) on 
students' motivation and reading achievement; and (3) To determine the difference in the effect of TBLand STAD on students' motivation and reading achievement.

\section{Research Methods}

This research was a true experimental research. In this research, there would be two treatments and two experimental groups. The first group would be given TBL and the second would be given STAD. Before learning process began, the pre-test would be done at both groups of students who applied the TBL and those who applied the STAD method. The pretest would include both reading achievement test and motivation questionnaire. At the end of the learning process, the two groups would be given post-test (reading achievement test and motivation questionnaire) to know the learning objectives that had been arranged.

In this research, there were two variables namely independent variable (TBL and STAD) and dependent variable (motivation and reading achievement).

Population in this research was the students of grade X of SMAN 2 Aikmel, East Lombok in academic year 2017/2018. The numbers of students were 273 students which divided into 7 classes. The sample in this research was class X IPA 2 and X IPS 2 by the number for each is 34 students. Sampling would be done by probability sampling technique by random sampling.

Instruments used in the data collection were reading achievement test and motivation questionnaire.

The data would be analyzed descriptively and quantitatively. The descriptive analysis would cover the mode, median, range, mean, standard deviation of the data and the distribution of frequency in histograms. The result from the descriptive analysis was meant to give information concerning the students' score. Quantitative analysis would be done by using two-way ANOVA for hypotheses testing.

\section{Theory}

Language learning aims to train students to care about the values of communication so that they can use the language appropriately. Littlewood (1984) states that language learning is the way to respond naturally to the needs of communication (both productive and receptive) hence, we must attempt to ensure the learners to always care of the values of communication of what they learned. Littlewood also stated that when the classroom is filled with the anxious situation, that is a constraint for learning. This further will make the learners feel unwilling to perform themselves in learning a second language. What the teachers do then is that they had to decline the exaggerated criticism for the learners' performance, but they attempt to give the learners to express themselves, and of course, the teachers had to be able to change the classroom to be relaxed and supportive.

From the explanation above it can be concluded that English language learning aims to provide the student's ability to communicate in English. To achieve an effective learning process, there must be togetherness between teachers and learners. The teacher had to be able to adjust the conditions and be flexible in the class to apply the techniques.

Theory of Teaching and Learning, The word learning, as used today, must be seen from two viewpoints. One viewpoint supposes learning as a process or activity. Later, another point of view stresses learning as a result or product. While teaching is an activity designed to generate improvements in learners to provide encouragement, support, and guidance for certain changes. While other experts, Nunan (1989) states that the main purpose of education is to establish the learning process, learning plans, and using apt strategies. According to Xiangui (2005) language instruction was viewed not just in term of providing comprehensible input but rather as helping students enter into the kinds of authentic social discourse situation and discourse communities that they would rather encounter outside the classroom (Xiangui 2005), further Brown (2007) stated that learning is gaining or getting knowledge of a subject or a skill by study, experience, or instruction. While teaching is defined as showing or helping someone to learn how to do something, providing with knowledge causing to know or understand.

From the definition of learning, there are some extracts can be taken. Firstly, learning is an acquisition or getting. Second, learning is retention of information or skill. Thirdly, retention implies storage system, memory, cognitive, and organization. Fourthly, learning involves active, conscious focus on and acting upon events outside, or inside the organization. Fifthly, learning is relatively permanent but subject to forgetting. Sixthly, learning involves some form of practice, perhaps reinforce practice. Finally, learning is a change in behavior.

Theory of Reading, Leipzig (2001) pointed out that reading is a multifaceted process involving word recognition, comprehension, fluency, and motivation. Learn how readers integrate these facets to make meaning from print.

Sari, L. D. P., Arifuddin, -, \& Yusra, K. (2018). Task-based learning and student team achievement division on students motivation and reading achievement. International Research Journal of Engineering, 
Reading is making meaning from print. It requires: firstly, we identify the words in print - a process called word recognition. Second, construct an understanding from them - a process called comprehension. Third, coordinate identifying words and making meaning so that reading is automatic and accurate - an achievement called fluency.

Reading Comprehension, reading comprehension means the understanding, evaluating, utilizing of information gained through the symbol of the text that involves any level concentration.

Harmer (2008) divides reading into two, namely: extensive reading and intensive reading. To get maximum result from their reading, students need to be involved in both extensive and intensive reading. A teacher encourages students to choose for themselves what to read and to do for pleasure and general language improvement. The lane is often teacher-chosen and directed. It is designed to enable students to develop specific receptive skills such as reading for gist (or general understanding -often called skimming), reading for specific information (often called scanning), reading for detailed comprehension or reading for inference (what is behind the words) and attitude.

Models of Reading, Bottom-up Model-it is a view, which assumes that a reader first decodes graphic symbols into sounds in order to build up a meaning, and a sense of texts. Furthermore, this model refers to the view that reading is a process of building letters into words, words into sentences, phrases and then proceeds to the overall meaning.

Top-down Model-unlike bottom-up model, the top-down model is a view, which assumes that a reader uses a prior knowledge and experience, as well as expectations in relation to the writer's message during reading, in order to process information.

Top-down models are described to be "concept-driven'. That is to say ideas or concepts in the mind of a reader trigger information processing during reading.

Task-Based Learning (TBL), Task-Based Learning refers to an approach based on the use of task as the core of planning and interaction in language teaching (Richard, 2001). Some of proponents (e.g. Willis, 1996) present it as logical development Communicative Language Teaching (CLT) since it draws on several principles that formed parts of CLT movement from 1980's namely, (1) activities that involve real communication as essential for language learning, (2) activities which language is used for carrying out meaningful task promote learning. Language that is meaningful to the learner supports the learning process.

Characteristic of Task-Based Learning (TBL), Task-Based Learning (TBL) is the latest trend in SLL approaches. It is undeniable that it has yielded a positive impact on teaching methodology, though; the proponents of task-based learning still very naturally in their emphasis and belief. Buyukkarci (2009) said there are some principles — that is so-called characteristic of TBL: First, instructed language learning should primarily involve natural or naturalistic language use and the activities are concerned with meaning rather than language. Second, instruction should favor learner-centeredness rather than teacher control. Third, since purely naturalistic learning does not normally lead to target-like accuracy, involvement is necessary in order to foster the acquisition of formal linguistic elements while keeping the perceived advantages of a natural approach. Fourth, this can be done best by providing opportunities for focus on the form, which will draw students' attention to linguistic elements as they arise incidentally in lessons whose prime focus is on meaning or communication. Fifth, communicative tasks are a particularly appropriate tool for such an approach. Sixth, more formal pre- or post-task language study may be useful. This may contribute to acquisition by leading or increasing noticing of formal features during communication. Finally, traditional approaches are ineffective and undesirable, especially where they involve passive formal instruction and practice separated from communicative work.

Richard (2001) summarized the key assumptions of Task-based Learning as follows: (1) the focus is on process rather than product, (2) basic element is purposeful activities and task that emphasize on communication and meaning, (3) learners learn language by interacting communicatively and purposefully while engaged in the activities and tasks, (4) activities and tasks can be either those that learners might need to achieve in real life, those that have pedagogical purpose specific to the classroom, (5) activities and tasks of TBL syllabus are sequenced according to difficulty, (6) the difficulty of task depends a range of factors including the previous experience of the learners, the complexity of the task, the language required to undertake the task, and the degree of support available.

Cycles of Task-Based Learning (TBL), Task-based learning (TBL) offers an alternative approach for language teachers. The lesson is based on the completion of central tasks, and the language studied is determined simultaneously as the students complete the task. Buyukkarci (2009) shows these certain stages:

Pre-task, Ellis (2006) states that the first phase is pre-task and explains the various activities that teachers and students can carry out before they start the task. The purpose of the pre-task phase is to prepare students to perform the task in ways that will help to promote acquisition.

Task, the students finish a task in pairs or groups by using the language resources as the teacher monitors and offers support. This second phase includes a lesson that is essentially conversational in nature and the explicit 
formulation of messages, also includes opportunities for students to take risks. Another process in this phase includes the shared goals and effective scaffolding for the learners' efforts for communication.

Planning, Students set up a short oral or written report to explain to the class what happened during their task. They then practice what they are going to say in their groups. Meanwhile, the teacher is available for the students to ask for a recommendation to clear up any language questions they may have. Having completed the task, students prepare to report on the outcome. Now the emphasis is on organization and accuracy. The teacher advises students on language and helps them correct any errors they make during this phase.

Report, Students then report back to the class orally or read the written report. The teacher chooses the order of when students will present their reports and may give the students some quick feedback on the content. At this stage, the teacher may also play a recording of others doing the same task for the students to compare. This phase has some pedagogic goals such as providing a repeat performance of the task, encouraging reflection on how the task was performed, and lastly encouraging forms that are problematic to the learner during the task. In short, it can be said that some or all of the groups should report briefly to the whole class. The others listen in order to compare findings or conduct a survey. The teacher may rephrase but not correct the language.

Analysis, The teacher then highlights relevant parts from the text of the recording for the students to analyze. They may ask students to notice interesting features within this text. The teacher can also highlight the language that the students used during the report phase for analysis.

Practice, finally, the teacher selects language areas to practice based upon the needs of the students and what emerged from the task and report phases. The students then do practice activities to increase their self-confidence and make a note of useful language. In more specific and applicable here are phases that should be followed by a teacher and students.

Student Team Achievement Divisions (STAD), this model of learning was developed by Slavin with his colleagues in Hopkins University. He further stated that student team achievement division (STAD) was the oldest and simplest method of cooperative learning that was widely used and it can be applied in science, language art, and other fields of knowledge. (Slavin, 1995)

Tiantong \& Sanit Teemuangsai (2013) said that STAD is a collaborative learning strategy in which small groups of learners with different levels of ability to work together to accomplish a shared learning goal. Students are assigned to four or five-member learning teams that are mixed in performance level, gender, and ethnicity. The teacher presents a lesson, and then students work together within their teams to make sure that all team members have mastered the lesson. Then all students take individual quizzes on the material, at which time they may not help one another. Students' quiz scores are compared to their own past averages, and points are awarded on the basis of the degree to which students meet or exceed their own earlier performance. These points are then summed to form team scores, and teams that meet certain criteria may earn certificates or other rewards

STAD drew on cooperative learning method which stresses on students mastering the materials through group learning and the group is responsible for their members. In STAD, the teacher conveys the content or skill in large group activities in the regular way, such as direct instruction and modeling, while students are provided with learning materials that they use in groups to master the content.

Components of Student Team Achievement Division (STAD)

Student Team Achievement Division (STAD)comprises five components (Slavin, 1995) as follow:

1) Class Presentation

In this part, a teacher introduces materials in class presentation.

2) Teams

The main function of a team is to ensure that all teammates are learning in particular to providing its members to do the quiz well. After presenting the material, the team is engaged in studying worksheet or other materials. What the members do is to discuss problems together, comparing answer, and correcting any misconception if teammates make a mistake.

3) Quizzes

After one or two sessions of teacher presentation and one or two of team practice, pupils take the individual quiz. Here, student individually is responsible for knowing the materials.

4) Individual Improvement Score

The purpose of the individual score is to know the progress or improvement of the scores after they are compared with the scores in the past.

Sari, L. D. P., Arifuddin, -, \& Yusra, K. (2018). Task-based learning and student team achievement division on students motivation and reading achievement. International Research Journal of Engineering,

IT \& Scientific Research, 4(2), 87-97. https://doi.org/10.21744/irjeis.v4n2.230 
5) Team Recognition

If teams' average score surpasses certain criteria, the teams may achieve a certificate or another reward.

\section{Motivation}

Dornyei (1998) states that motivation powers people and gives direction. Chun (2010) identifies motivation as the learner's orientation relating to the goal of learning a second language. Another way to say this is that motivation is goal-directed behavior. In short, it can be said that motivation is a commando in one's mind that must exist to reach the goal.

\section{Results and Analysis}

\subsection{Findings}

\section{a) Data Description}

Data on reading achievement and motivation consisted of pre-test and post-test data. The pre-test was given to the two groups - TBL and STAD group - before treatment. This test aimed at knowing the initial ability of students on the material experimented. Post-test, on the other hand, was conducted after treatment. The purpose of post-test was to identify the students' ability on reading achievement and motivation after they were given the treatment.

Table 1

Descriptive statistics of reading achievement and motivation

\begin{tabular}{llrrr}
\hline & Pre-Post & \multicolumn{1}{c}{ Mean } & Std. Deviation & N \\
\hline \multirow{3}{*}{ Reading } & Pretest & 24.1176 & 7.48236 & 34 \\
& Posttest & 76.5000 & 12.26537 & 34 \\
& Total & 50.3088 & 28.24692 & 68 \\
\multirow{3}{*}{ Motivation } & Pretest & 2.8559 & .42153 & 34 \\
& Posttest & 3.7235 & .32479 & 34 \\
& Total & 3.2897 & .57488 & 68 \\
\hline
\end{tabular}

b) The Effectiveness of Task-Based Learning (TBL) on students' motivation and reading achievement

The data used in this study were the result of reading achievement test and motivational questionnaire from the post-test. The data were analyzed by using ANOVA (multivariate test). The result of the analysis was served in the following table:

Table 2

Multivariate tests

\begin{tabular}{llrrrrr}
\hline Effect & & Value & \multicolumn{1}{c}{ F } & Hypothesis df & Error df & \multicolumn{1}{l}{ Sig. } \\
\hline \multirow{5}{*}{ Pre_Post } & Pillai's Trace & .841 & $171.776^{\mathrm{b}}$ & 2.000 & 65.000 & .000 \\
& Wilks' Lambda & .159 & $171.776^{\mathrm{b}}$ & 2.000 & 65.000 & .000 \\
& Hotelling's Trace & 5.285 & $171.776^{\mathrm{b}}$ & 2.000 & 65.000 & .000 \\
& Roy's Largest Root & 5.285 & $171.776^{\mathrm{b}}$ & 2.000 & 65.000 & .000 \\
\hline
\end{tabular}

The result of the analysis showed that the F value for Pillae Trace, Wilk Lambda, Hotelling Trace, Roy's Largest Root had significance (sig.): 0.000 which smaller than $0.05(0.000<0.05)$. It meant that $\mathrm{F}$ value for Pillae Trace, Wilk Lambda, Hotelling Trace, Roy's Largest Root was all significant. Thus, there was a significant effect of Task-Based Learning (TBL) on students' motivation and reading achievement.

c) The Effectiveness of Student Team Achievement Division (STAD) on students' motivation and reading achievement

The data used in this study were the result of reading achievement test and motivational questionnaire from the post-test. The data were analyzed by using ANOVA (multivariate test). The result of the analysis 
was served in the following table:

Table 3

Multivariate tests ${ }^{\mathrm{a}}$

\begin{tabular}{llrrrrc}
\hline Effect & & Value & \multicolumn{1}{c}{ F } & Hypothesis df & Error df & \multicolumn{1}{c}{ Sig. } \\
\hline \multirow{4}{*}{ Pre_Post } & .893 & $271.378^{\mathrm{b}}$ & 2.000 & 65.000 & .000 \\
& Pillai's Trace & .107 & $271.378^{\mathrm{b}}$ & 2.000 & 65.000 & .000 \\
& Wilks' Lambda & 8.350 & $271.378^{\mathrm{b}}$ & 2.000 & 65.000 & .000 \\
& Hotelling's Trace & 8.350 & $271.378^{\mathrm{b}}$ & 2.000 & 65.000 & .000 \\
& Roy's Largest Root & & & & & \\
\hline
\end{tabular}

The result of the analysis showed that the F value for Pillae Trace, Wilk Lambda, Hotelling Trace, Roy's Largest Root had significance (sig.): 0.000 which smaller than $0.05(0.000<0.05)$. It meant that $\mathrm{F}$ value for Pillae Trace, Wilk Lambda, Hotelling Trace, Roy's Largest Root was all significant. Thus, there was a significant effect of Student Team Achievement Division (STAD) on students' motivation and reading achievement.

d) The Effectiveness of Task-Based Learning (TBL) and Student Team Achievement Division (STAD) on students' motivation and reading achievement

Table 4

Multivariate tests ${ }^{\text {a }}$

\begin{tabular}{llrrrrr}
\hline \multicolumn{1}{l}{ Effect } & Value & \multicolumn{1}{c}{ F } & Hypothesis df & Error df & \multicolumn{1}{l}{ Sig. } \\
\hline \multirow{4}{*}{ CL } & Pillai's Trace & .106 & $3.869^{\mathrm{b}}$ & 2.000 & 65.000 & .026 \\
& Wilks' Lambda & .894 & $3.869^{\mathrm{b}}$ & 2.000 & 65.000 & .026 \\
& Hotelling's Trace & .119 & $3.869^{\mathrm{b}}$ & 2.000 & 65.000 & .026 \\
& Roy's Largest Root & .119 & $3.869^{\mathrm{b}}$ & 2.000 & 65.000 & .026 \\
\hline
\end{tabular}

The result of the analysis showed that the F value for Pillae Trace, Wilk Lambda, Hotelling Trace, Roy's Largest Root had significance (sig.): 0.026 which smaller than $0.05(0.026<0.05)$. It meant that $\mathrm{F}$ value for Pillae Trace, Wilk Lambda, Hotelling Trace, Roy's Largest Root was all significant. Thus, there was a significant effect of Task-Based Learning (TBL) and Student Team Achievement Division (STAD) on students' motivation and reading achievement.

e) The Comparison of the Effectiveness of Task-Based Learning (TBL) and Student Team Achievement Division (STAD) on students' motivation and reading achievement

The data used in this test was the data gained from post-test including reading achievement test and motivational questionnaire for both groups. This data was analyzed by using Multivariate Test. This analysis aimed at examining how effective TBL compared to STAD viewed from variable learning motivation and reading achievement. This analysis was conducted using SPSS 17.0 for Windows. The following was the result of statistical analysis of Multivariate Test.

Tabel 5

Multivariate tests ${ }^{\text {a }}$

\begin{tabular}{llrrrrr}
\hline Effect & & Value & \multicolumn{1}{c}{$\mathrm{F}$} & \multicolumn{1}{c}{ Hypothesis df } & \multicolumn{1}{c}{ Error df } & \multicolumn{1}{l}{ Sig. } \\
\hline \multirow{4}{*}{ Intercept } & Pillai's Trace & .941 & $520.081^{\mathrm{b}}$ & 2.000 & 65.000 & .000 \\
& Wilks' Lambda & .059 & $520.081^{\mathrm{b}}$ & 2.000 & 65.000 & .000 \\
& Hotelling's Trace & 16.002 & $520.081^{\mathrm{b}}$ & 2.000 & 65.000 & .000 \\
& Roy's Largest Root & 16.002 & $520.081^{\mathrm{b}}$ & 2.000 & 65.000 & .000 \\
& Pillai's Trace & .106 & $3.869^{\mathrm{b}}$ & 2.000 & 65.000 & .026 \\
$\mathrm{E} \mathrm{CL}$ & Wilks' Lambda & .894 & $3.869^{\mathrm{b}}$ & 2.000 & 65.000 & .026 \\
& Hotelling's Trace & .119 & $3.869^{\mathrm{b}}$ & 2.000 & 65.000 & .026 \\
& Roy's Largest Root & .119 & $3.869^{\mathrm{b}}$ & 2.000 & 65.000 & .026 \\
\hline
\end{tabular}

Sari, L. D. P., Arifuddin, -, \& Yusra, K. (2018). Task-based learning and student team achievement division on students motivation and reading achievement. International Research Journal of Engineering, IT \& Scientific Research, 4(2), 87-97. https://doi.org/10.21744/irjeis.v4n2.230 
From the table above, it was shown that the significance value of Hotelling's Trace was smaller than 0.005 (Hotelling's Trace Value > 0.05) and the value of F count was bigger than F table ( $\mathrm{F}$ count $>\mathrm{F}$ table). Its result showed that there was no difference result of TBL compared to STAD viewed from motivation and reading achievement.

\subsection{Discussion}

In this study, the method applied was Task-Based Learning (TBL) and Students Team Achievement Division (STAD) and the teaching materials were recounted text, narrative text, news item, procedure text and descriptive text at grade X students of SMAN 2 Aikmel in the academic year 2017-2018. Some points which were examined in this study were: First, to describe the effectiveness of TBL and STAD; second, to determine the difference of effectiveness from each method to enhance students' motivation and reading achievement.

\section{a) The Effectiveness of TBL and STAD}

To know the effectiveness of TBL and STAD viewed from reading achievement, the criteria used was the passing grade (minimum limit accomplishment). The effectiveness of study was defined as the average accomplishment of the class which surpassed the passing grade set for each unit of topic or material either individually or in the group. In this study, the passing grade used was 75 . This was based on the passing grade set at SMAN 2 Aikmel. While the standard score for motivation was 3,5 in the scale of 1,0-5,0 with category good.

The data revealed that from 34 students there were only 4 students $(12 \%)$ who reached the standard score 3,5 in the pre-test of TBL group. While in the post-test there was a significant improvement of those students who reached the standard score, that was 20 students (60\%). This improvement could also be seen in the mean score. In the pre-test, the mean score of TBL group was 2,8 while in the post-test was 3,8 . From these data, it was obvious that TBL was effective to increase students' motivation. The improvement of motivation was also followed by students who used STAD method. In the pre-test, from the 34 students, there were 4 students (12\%) who reached the standard score 3,5. While for the post-test, there were 26 students $(77 \%)$ who reached the standard score. The improvement could also be seen from the mean score. In the pre-test, the mean score of STAD students was 2,8 and the post-test was 3,7. Based on these data, it was obvious that STAD was effective to increase students' motivation.

In STAD class, students were given chance through a worksheet to develop their ability independently and involved in exploring, questioning, and communicating process. This process enabled students to gain positive independence, individual accountability, group processing, and interpersonal skill. The purpose of STAD was to motivate students to encourage and help one another to master skill presented by the teachers. In short, students needed to collaborate effectively with others, so the teachers needed to teach the appropriate communication, leadership, trust-building, decision-making and conflict management skills.

On the other hand, learning English with TBL was effectively viewed from motivation and reading achievement. This was due to students' active participation in learning English through discussion and to complete the tasks with their partner or group members. This idea was in line with Kavaliauskiene (2005) who stated that teaching through tasks created favorable learning conditions for students who studied English. This activity made the students aware of the function of language as a means of communication that could be applied in real world. She further added that TBL can maximalize students' potency in learning and could provide a comfortable class environment that would lead to real-life activities. In this activity, students were also given a chance to practice the language and the students could explore, communicate, question and analyze the tasks. This was done through steps of learning such as pre-task and task. The variety of task encouraged the students to work enthusiastically. This was important because it grew students' motivation in learning English. TBL significantly increased students' motivation in learning. This was also supported by Ruso (2005) who stated that TBL was helpful in improving students' motivation and learning. It encouraged students to practice the target language.

By applying both methods, TBL and STAD, it could be concluded that both methods were effective to increase students' motivation and reading achievement.

\section{b) The Comparison of TBL and STAD}

Based on the result of the statistical analysis in this study, TBL and STAD equally had a positive impact on students' motivation and reading achievement. Both methods were not significantly different. In other words, 
both were effective in increasing students' motivation and reading achievement. Thus, it could be said that the effect of TBL and STAD to enhance students' motivation and reading achievement was not different. The effectiveness of TBL and STAD was based on the fact that both of them were student-centered teaching activities.

\section{Conclusion}

Based on the data analysis and discussion above, it could be concluded that:

a) The application of Task-Based Learning (TBL) is able to effectively enhance students' motivation and reading achievement of grade X students of SMAN 2 Aikmel in the academic year 2017-2018.

b) The application of Student Team Achievement Division (STAD) is able to effectively enhance students' motivation and reading achievement of grade X students of SMAN 2 Aikmel in the academic year 2017-2018.

c) There is no difference in the effect of TBL and STAD in enhancing students' motivation and reading achievement. Both methods equally have positive impact to enhance students' motivation and reading achievement of grade X students of SMAN 2 Aikmel in the academic year 2017-2018.

Conflict of interest statement and funding sources

The authors declared that they have no competing interest. The study was financed by personal funding.

\section{Statement of authorship}

The authors have a responsibility for the conception and design of the study. The authors have approved the final article.

\section{Acknowledgments}

Researchers would like to thank all people and parties who have assisted me in completing this research. I would like to thank the head of SMAN 2 Aikmel, East Lombok Regency who has given the permission to conduct this research. My gratitude also is delivered to all families who have given blessing, prayer, and motivation in completing this research.

Sari, L. D. P., Arifuddin, -, \& Yusra, K. (2018). Task-based learning and student team achievement division on students motivation and reading achievement. International Research Journal of Engineering, IT \& Scientific Research, 4(2), 87-97. https://doi.org/10.21744/irjeis.v4n2.230 


\section{References}

Bilsborough, K. (2013). TBL and PBL: Two learner-centred approaches. TBL and PBL: Two learner-centred approaches| TeachingEnglish| British Council| BBC.

Brown, H. D. (2000). Principles of language learning and teaching.

Brown, H. Douglas. 2000. Teaching by Principles. New York: Longman.

Chapman, C. (2007). Book Review: Creating a Learning School by David Middlewood, Richard Parker and Jackie Beere. London: Paul Chapman Publishing, 2005, ISBN 1412910420 (pbk), ISBN 1412910412 (hbk), 19.99. Educational Management Administration \& Leadership, 35(4), 595-596.

David, N. (2004). Task-based language teaching.

Ebel, R. L. (1972). Essentials of educational measurement.

Ellis, R. (2003). Task-based language learning and teaching. Oxford University Press.

Ellis, R. (Ed.). (2005). Planning and task performance in a second language (Vol. 11). John Benjamins Publishing.

Gardner, R. (1985). C. 1985. Social psychology and second language learning: The role of attitudes and motivation.

Ginaya, G., Rejeki, I. N. M., \& Astuti, N. N. S. (2018). The effects of blended learning to students' speaking ability. International Journal of Linguistics, Literature and Culture (IJLLC), 4(3), 1-14.

Harmer, J. (1998). How to Teach English: an Introduction to the Practice of English Language Teaching, England.

Harmer, J. (2001). The practice of English language teaching. London/New York.

Littlewood, W., \& William, L. (1981). Communicative language teaching: An introduction. Cambridge university press.

Macías, E. I. P., Cedeño, H. A. C., \& Chávez, G. M. R. (2018). Importance of Improving Resilience in TeachingLearning Process of Students with Disabilities. International Research Journal of Management, IT and Social Sciences (IRJMIS), 5(2), 120-128.

Macías, E. I. P., Cedeño, H. A. C., \& Chávez, G. M. R. (2018). Importance of Improving Resilience in TeachingLearning Process of Students with Disabilities. International Research Journal of Management, IT and Social Sciences (IRJMIS), 5(2), 120-128.

MacLeod, M. (2007). Types of reading. URL: http://fis. ucalgary. ca/Brian/611/readingtype. html.

Nunan, D. (1991). Language teaching methodology (Vol. 192). New York: prentice hall.

Richards, J. C., \& Rodgers, T. S. (2014). Approaches and methods in language teaching. Cambridge university press.

Slavin, R. E. (1985). An introduction to cooperative learning research. In Learning to cooperate, cooperating to learn (pp. 5-15). Springer, Boston, MA.

Stevens, J. P. (2012). Applied multivariate statistics for the social sciences. Routledge.

Thorndike, R. (1976). Reading comprehension in fifteen countries. New horizons in reading, 500-507.

Willis, J. (1996). A flexible framework for task-based learning. Challenge and change in language teaching, 52-62. 


\section{Biography of Authors}

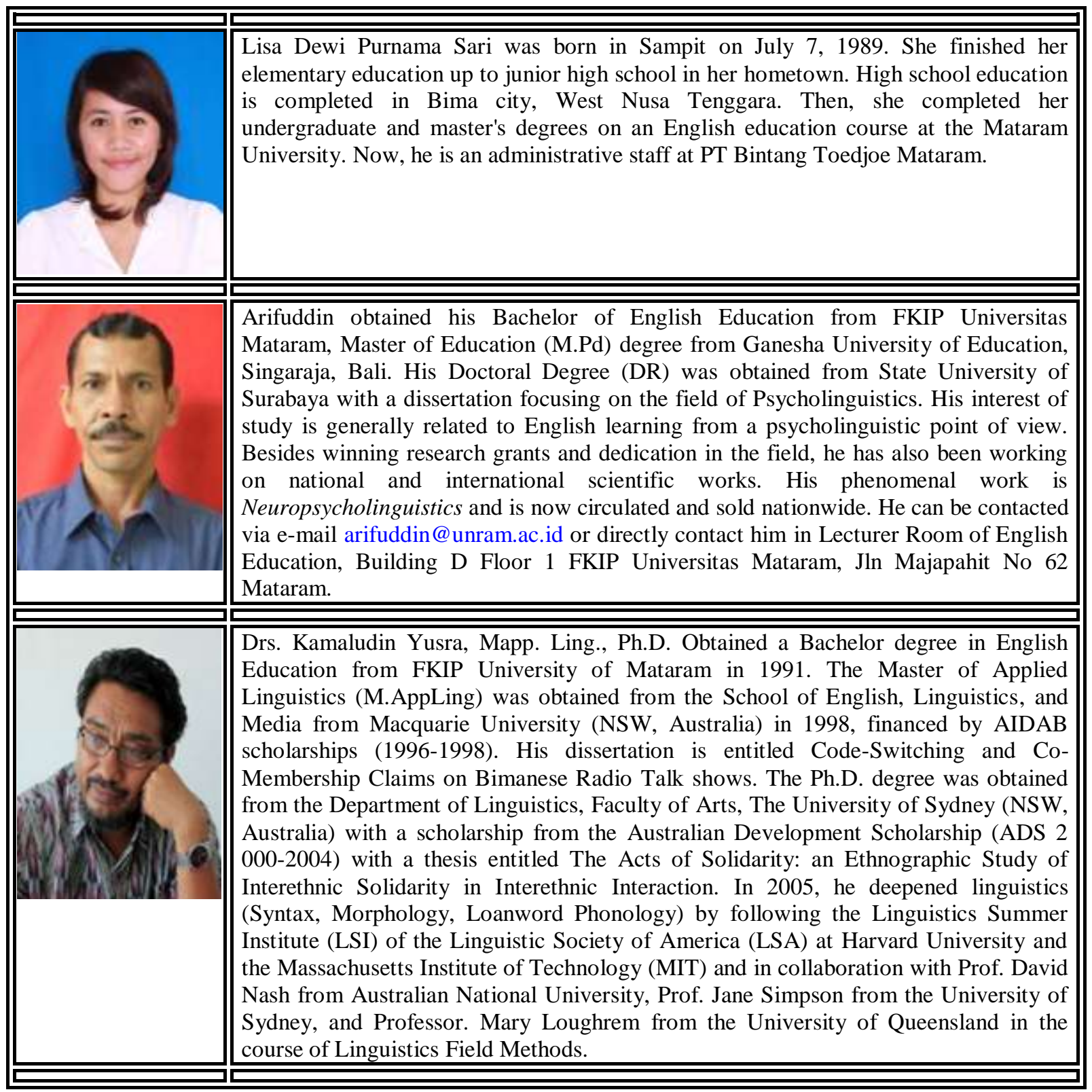

Sari, L. D. P., Arifuddin, -, \& Yusra, K. (2018). Task-based learning and student team achievement division on students motivation and reading achievement. International Research Journal of Engineering, IT \& Scientific Research, 4(2), 87-97. https://doi.org/10.21744/irjeis.v4n2.230 